\title{
POLOPALO: TINJAUAN ETNO ORGANOLOGI AKUSTIK
}

\author{
Oleh: \\ Rahmawati Ohi \\ Sendratasik Universitas Negeri Gorontalo \\ Email: 08rahmawatiohi@gmail.com
}

\begin{abstract}
$\underline{\text { Abstrak }}$
Polopalo merupakan instrumen musik yang mempunyai kemiripan dengan bentuk mulut buaya berbahan dasar bambu talilo huido, dimana polopalo pentatonis terbagi menjadi 4 jenis berdasarkan bunyinya yaitu moelenggengo, mobulongo, moduludo dan motoliyongo. Membicarakan polopalo dan perkembangannya, realita menunjukkan bahwa saat ini mengalami penurunan kualitas fungsi yang disebabkan oleh kekeliruan intepretasi, selain itu keunikan organologi-akustik dan masih kurangnya informasi menjadi sebuah permasalah yang menarik untuk di telaah lebih dalam berdasarkan konteks budaya dan perkembangan sains. Metode penelitian menggunakan campuran sekuensial, penguraian konteks budaya dilakukan dengan wawancara kualitatif sedangkan perkembangan sains dilakukan dengan survey dan pengukuran terhadap instrumen itu sendiri untukmengetahui faktor intra musikal. Hasil penelitian menunjukkan bahwa polopalo pentatonis mempunyai relasi aspek perkembangan sains dengan konteks yang bukan hanya terletak pada bentuk dan akustik, tetapi juga nilai guna dan dampak yang diakibatkan dalam aktivitas masyarakat.
\end{abstract}

Kata kunci: Polopalo, organologi, akustik

\begin{abstract}
Polopalo is a musical instrument that has a similarity with the shape of a crocodile's mouth made from talilo huido bamboo, where the pentatonic polopalo is divided into 4 types based on its sound, namely moelenggengo, mobulongo, moduludo and motoliyongo. Talking about polopalo and its development, reality shows that currently there is a decline in the quality of function caused by misinterpretation, besides that the uniqueness of the organology-acoustic and the lack of information is an interesting problem to be studied more deeply based on the cultural context and scientific developments. The research method used a sequential mixture, the decomposition of the cultural context was carried out by qualitative interviews, while the development of science was carried out by surveying and measuring the instrument itself to determine intra-musical factors. The results showed that the pentatonic polopalo has a relationship between aspects of the development of science with a context that lies not only in form and acoustics, but also the value of use and the impact that results in community activities.
\end{abstract}

Keyword : Polopalo, Organology, Acoustics. 


\section{A. Pendahuluan}

Polopalo merupakan instrumen musik, ikon warga Gorontalo yang mempunyai keunikan pada organologiakustik. Bay (dalam Ohi: 2014) memberikan penjelasan bahwa polopalo merupakan instrumen perkusi yang secara organologi mempunyai kemiripan bentuk dengan mulut, rahang buaya sedangkan secara akustik hadir melalui karakter bunyi yang berkaitan dengan falsafah masyarakat.

Membicarakan organologi-akustik polopalo maka tidak bisa lepas dari material bahan yang membuatnya, bambu talilo huidu merupakan pilihan untuk membuat polopalo karena mempunyai kadar air yang rendah. Filosofi masyarakat, bahwa bambu merupakan tanaman yang mempunyai nilai guna beragam di tengah-tengah aktivitas masyarakat; salah satunya adalah berkesenian sebagai salah satu unsur kebudayaan.

Perkembangan kajian organologi akustik dewasa ini mengalami perkembangan yang cukup baik, dengan seringkali terdapat diskurus mengenai pendekatan prinsip kebaruan dengan mempertimbangkan aspek sains dengan konteks kebudayaan yang membungkus instrumen musik tersebut.

Membicarakan Polopalo pentataonis dan perkembangannya dalam aktivitas masyarakat maka saat ini seringkali terjadi disfungsi atau penurunan kualitas nilai guna karena intepretasi yang keliru sehingga memposisikan Polopalo dalam kondisi kritis, tetapi dalam kondisi inilah seringkali fungsi latens instrumen hadir dalam memberikan nilai terhadap bidangbidang kehidupan masyarakat. Hadirnya pendekatan sains dengan budaya dalam memahami organologi akustik sebuah instrumen musik, khususnya polopalo jenis pentatonik yang terus mengalami penurunan kualitas fungsi dalam aktifitas masyarakat merupakan sebuah peluang bagi pengembangan nilai-nilai ilmu pengetahuan dan teknologi berdasarkan kearifan budaya lokal jenius.

\section{Aspek Etic Organologi Focoult dan Hadot}

Instrumen musik merupakan wujud integrasi dari berbagai aktivitas manusia, imaji kebebasan dan menjelaskan tentang relasi kajian epistemik dengan etika yang merupakan fokus perhatian dalam relasi sains dan konteks budaya sehingga dapat memahami aktivitas, penciptaan instrumen (etik), dimensi, momen dan sejarah sains berdasarkan epistemik dalam konteks budaya dan perkembangan pengetahuan sains sebuah instrumen musik.

Focoult dan Hadot (dalam John Tresh et al: 2013) menjelaskan konsep etik instrumen musik, yang merupakan satu 
kesatuan tidak terpisah dari teori atau praktik, tetapi sebagai bentuk kehidupan, dengan cita-cita yang berbeda, kode moral, kegiatan, dan pemahaman diri. Foucoult memberikan 4 tahapan dalam memberikan deskripsi tentang organologi ;

1. Disposisi atau karakter material instrument: sifat dan konfigurasi elemen instrumen, bahan dan bagian-bagiannya.

2. Modus mediasi instrumen : apakah aksinya dianggap autonomous atau pasif, diatur atau transparan, tersembunyi atau terlihat

3. Pemetaan terukur bagian instrumen. Pemetaan dilakukan dengan pertimbangan elemen yang berbeda, mungkin agak rumit seperti dalam musik, banyak faktor yang mempengaruhi kualitas instrumen termasuk udara, suara, komposer, pemain, instrumen lain, dan pendengar, termasuk mengenai orkestrasi dan aturan komposisi; dimana pengetahuan mereka termasuk bagian fenomena yang diselidiki, pengamat atau eksperimen, dan elemen lainnya dalam sistem eksperimental, serta aturan metode, protokol laboratorium, lembaga ilmiah, dan pola bergerak antara pengamatan secara general.
4. Faktor kelayakan atau telos nilai guna instrumen, atau distribusinya. Telos berkaitan dengan nilai guna komunal instrumen yang digunakan; apa konteks dan penggunaan sosialnya, dan hubungan sosial, ekonomi, dan politik yang mereka ungkapkan. Pada level kelayakan, kehadiran konsepsi yang lebih luas dari tujuan instrumen (seperti yang disarankan Hadot dalam kritiknya terhadap Foucault): bukan hubungan instrumen dengan dirinya sendiri tetapi didukung untuk penggunanya dan mereka yang terpapar produkproduknya, serta penilaiannya pada keseluruhan kolektif. Sehingga, kita dapat mempertimbangkan hubungan instrumen yang terlihat bagian dari alam, atau kosmos secara keseluruhan

\section{Filosofi Akustik}

Hui (2011: 32) memberikan penjelasan mengenai akustik dari sisi obyektifitas yaitu frekuensi yang berhubungan dengan pitch secara persepsi subyektif. Interpretasi relasi pitch dengan frekuensi merupakan sebuah metaphor budaya, karena perbedaan modal budaya merefleksikan perbedaan sensasi-persepsi bunyi yang di dengar; contoh sederhana 
adalah persepsi terhadap pitch tinggi dan rendah di dunia barat didefinsikan berdasarkan getaran bunyi, sedangkan kebudayaan Indian mempersepsikan bunyi tinggi rendah dengan kata tua muda, berbeda lagi di Cina yang mempergunakan bersih dan kotor dalam mempersepsi bunyi yang didengar. Fakta tersebut memberikan gambaran bahwa setiap kebudayaan memiliki simbol ekspresi yang berbeda dalam mempersepsikan bunyi.

Alperson (1994) bahwa bunyi, musik sudah sejak dulu mempunyai hubungan dengan filosofi yang berkaiatan dengan aktivitas, proses mendegar dan membuatmusik. Banyak negara yang menggunakan musik sebagai bagian dari furnitur dalam dunia, faktor inilah yang memberikan landasan bahwa masyarakat memahami musik dari sisi material dan makna. Tinjauan material bahan memberikan sebuah intepretasi bahwa konsep bunyi setiap instrumen pasti berbeda-beda. Hanslick (dalam Alperson: 1994) memberikan penjelasn bahwa makna musik memliki hubungan dengan budaya masyarakat yang membentuk, musik merupakan mimesis dari alam dan ekspresi gambaran aktivitas budaya masyarakat, sebagai mimesisdari alam adalah bunyi yang dibentuk dari suara burung, dimana suara burung merupakan bentuk skalar, tidak ada melodi harmoni namun sebuah pola irama yang tertuang dalam instrumen ritmis. Tetapi apabila sistem ekspresi bekerja engan sistem filosofi maka yang muncul adalah sebuahmelodi dan harmoni yang merupakan pengembangan dari pola irama bunyi burung. Seperti contoh dibawah ini.

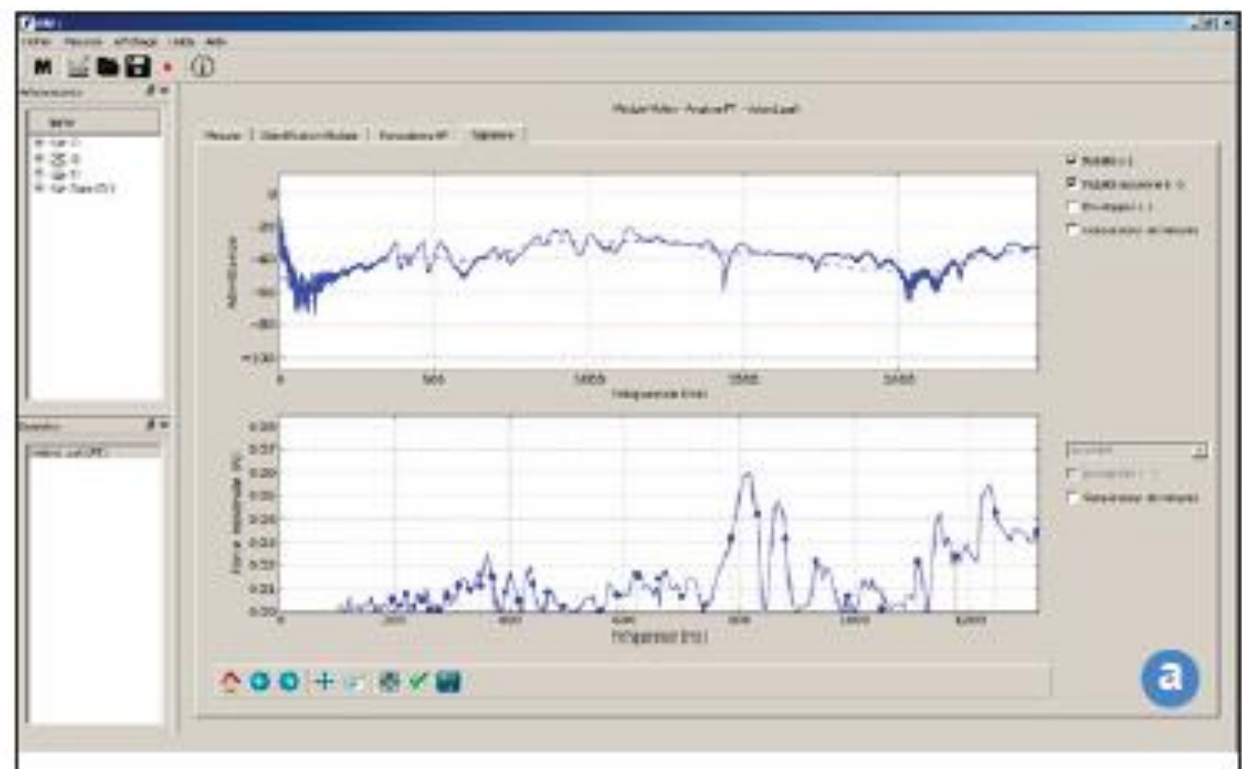

Sumber : Doutoth Vincent and Curtit Martee 
An aid to innovation in instrument-making: a collaborative approach between workshops and research laboratories

Acoustics in Practice International e-Journal of the European Acoustics Association (EAA) Vol. 2 • No. 1 • January 2014

\section{Manifest-Latens}

Merton (dalam Kaplan dan Manners: 2002) memberikan penjelasan mengenai keutuhan fungsional masyarakat, yakni bahwa segala sesuatu yang berhubungan fungsional dengan segala sesuatu yang lain dan bahwa segala unsur budaya melaksanakan fungsi dan tidak ada satu unsur lain yang mampu melaksanakan fungsi yang sama. Budaya tidak berintegrasi secara sempurna atau dapat beintegrasi hingga taraf-taraf tertentu. Berbagai unsur budaya dapat melaksanakan sesuatu fungsi yang sama, disfungsional mempunyai makna bahwa unsur tersebut dapat menghasilkan tekanan terhadap keterpiaraan sistem. Merton menambahkan bahwa untuk menjernihkan konsep fungsi maka memperkenalkan manifest-latens sebagai sebuah pendekatan dalam tindak budaya. Fungsi manifest sebagai fungsi yang dikehendaki, sedangkan latens adalah yang tidakdikehendaki. Relasi manifestlatens sebagai sebuah konsekuensi obyektif inilah yang dapat bekerja secara metaphor atau bolak balik.

\section{B. Metode Penelitian}

Penelitian ini menggunakan metode campuran sekuensial/bertahap. Cresswell (2011:22-23) menjelaskan bahwa metode tersebut merupakan prosedur-prosedur dimana di dalamnya peneliti berusaha menggabungkan atau memperluas penemuan-penemuannya yang diperoleh dari satu metode dengan penemuanpenemuannya darimetode lain. Konsep ini dapat dilakukan dengan melakukan interviwe kualitatif terlebih dahulu untuk mendapatkan penjelasan-pnejelasan yang memadai, lalu diiukuti dengan metode kuantitatif untuk mengekplorasi obyek tersebut melalui pengukuran.

\section{SKEMA PENELITIAN}

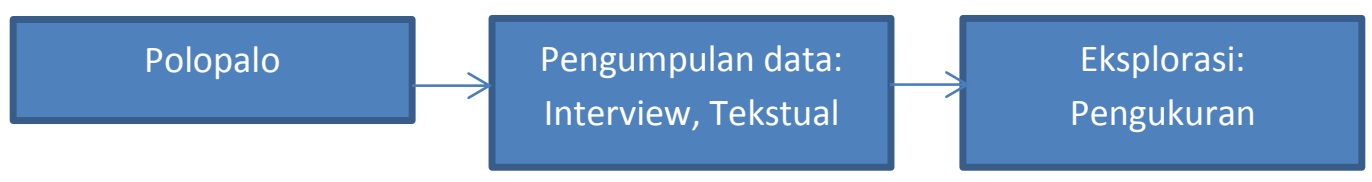

Skema 1

Konsep Penelitian Etno Organologi Akustik Polopalo 


\section{Hasil dan Pembahasan}

Polopalo merupakan instrumen musik dengan konsep perpaduan saintifik dengan budaya masyarakat, relasi aspek sains budaya memberikan sebuah intepretasi baru bahwa tinjauan etno organologi akustik menggambarkan relasi etik dengan filosofi budaya, direfleksikan dalam 4 aspek utama karakter instrumen polopalo yaitu mobulongo, moduloduo, moelenggengo dan motoliyongo.
Moelenggengo merupakan polopalo dengan bunyi yang kurang nyaring sedangkan motoliyongo merupakan polopalo yang mempunyai bunyi nyaring. Sedangkan isian ditengah adalah mobulongo dan modulodu'o.

Aspek perkembangan sains dalam wilayah ini terbagi menjadi empat faktor yaitu: material bahan, organologi instrumen, akustik yang dihasilkan dan relasi bunyi antar polopalo.

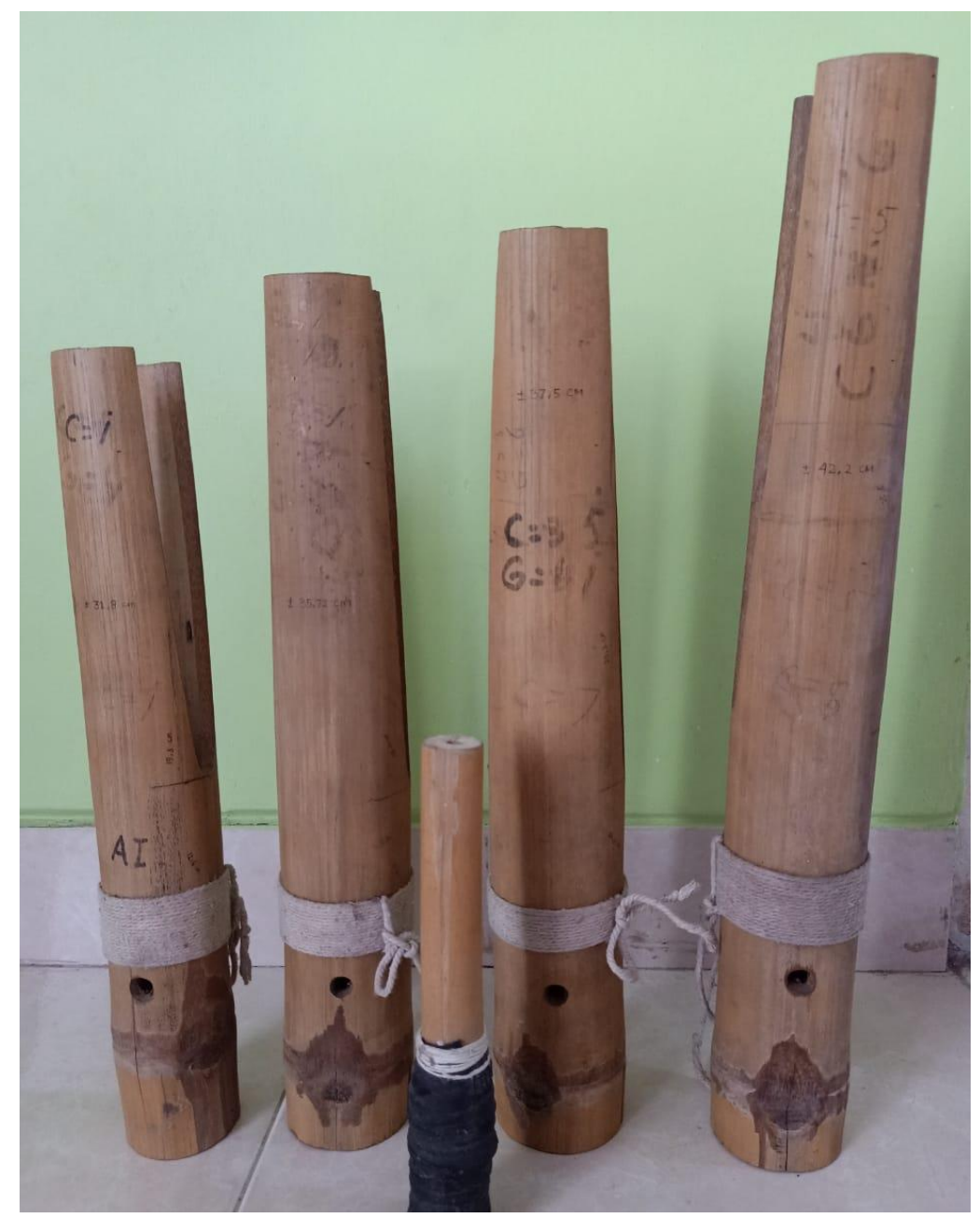

Gambar 1

Polopalo Pentatonik (Motoliyongo, Mobulongo, Moduloduo dan Moelenggengo)

Sumber : Dokumntasi Rahmawati Ohi: 2018 


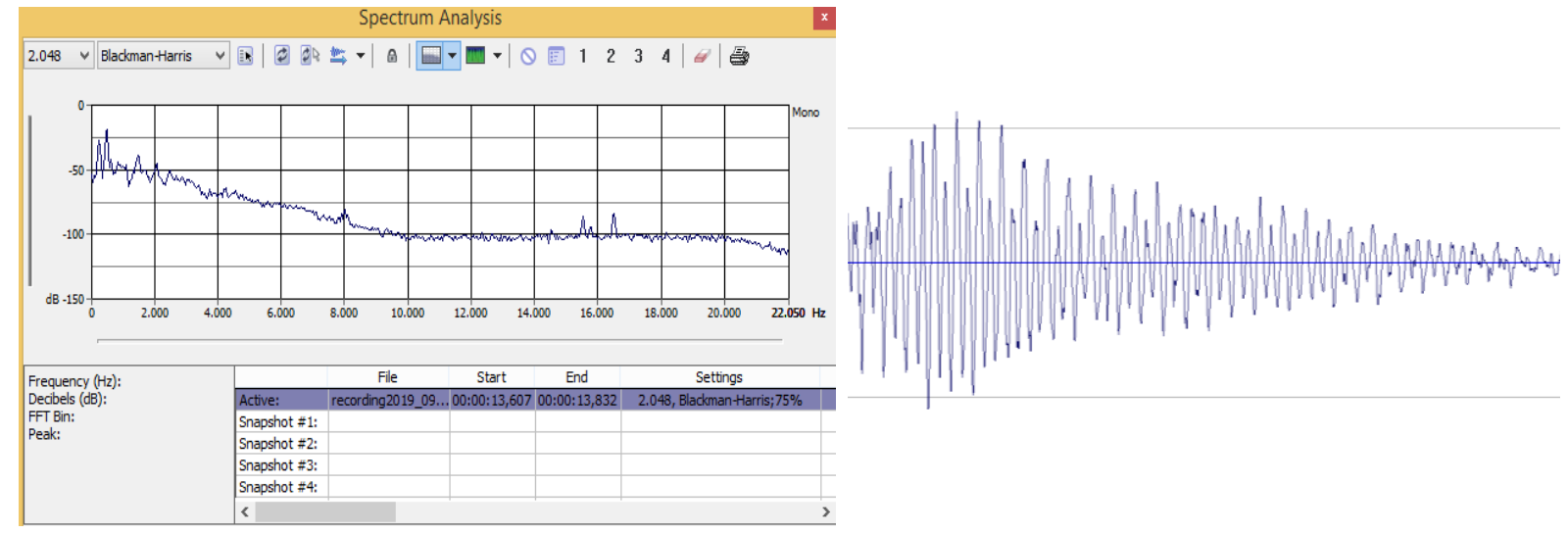

Gambar 2

Bunyi Polopalo jenis Moduloduo beserta Spektrum Vibrasinya

Analisa : Sonic Foundary 8.0

Pemilihan bambu gunung atau talilo huidu selain mempunyai karakter pada kadar air yang rendah, bambu bagi masyarakat Gorontalo mempunyai filosofi yang erat, karena bambu mampu beradaptasi dengan berbagai lingkungan dan kondisi. Konteks bagian polopalo terdiri dari lubang yang terletak di bawah, yang berfungsi untuk menjadikan bunyi nyaring atau tidak, selain itu konsep rahang atau bentuk yang mirip seperti mulut buaya merupakan sebuah tanda terhadap konsep dualitas filosofi masyarakat.

Polopalo jenis pentatonik merupakan salah satu instrumen tradisi, dimana bunyi dalam konteks budaya mempunyai hubungan dengan fungsi dan filosofi masyarakat tentang kehidupan. Bagi masyarakat Gorontalo, bunyi diidentifikasi secara obyektif dengan istilah frekuensi tinggi atau rendah. Proses mendengar yang terjadi oleh masyarakat Gorontalo ketika mempersespsikan bunyi dalam istilah "frekuensi" bukan pitch merupakan sebuah keunikan karena frekuensi bersifat intepretasi kognitif, mempunyai ukuran.

Polopalo pentatonis terdiri dari empat jenis yaitu motoliyongo, modulodu'o, mobulongo dan moelenggengo. Bunyi motoliyongo merupkan jenis polopalo dengan suara melengking, merupakan mimetik dari suara burung pipit yang bermakna berjiwa besar, pemberani, cerdik dan lincah, tinjauan aspek suasana menggambarkan perasaan gembira karena permulaan hari

Modulodu'o merupakan bunyi yang sangat erat dengan kehidupan masyarakat yang kuat dan mampu menghadapi segala tantangan, merupakan mimetik dari suara 
burung $\mathrm{Pa}$ 'o. Keterkaitan dengan suasana yang kurang aman atau mengancam sehingga seseorang harus mampu menghadapi kondisi tersebut.

Moelenggengo merupakan bunyi polopalo dengan frekuensi paling rendah, yang dikaitkan dengan bunyi burung kakak tua yang menyatakan suasana masyarakat yang penuh persahabatan. Sedangkan mobulongo merupakan bunyi yang dimemesiskan dengan suara ayam jago yang menandakan kondisi masyarakat tenang penuh kedamaian.

Telos atau nilai guna sebuah obyek dalam masyarakat. Polopalo pentatonik pada awalnya, abad 18 berfungsi sebagai media komunikasi masyarakat karena faktor demografi dan jangkauan bunyi, digunakan sebagai alarm adanya bahaya. Faktor demografi yang dimaksud adalah bahwa pada waktu itu jarak antara rumah satu dengan yang lain masih jauh, sehingga dibutuhkan sebuah alat yang mampu mengeluarkan bunyi dengan jangkauan frekuensi yang jauh; sehingga dipilih polopalo. Apabila masyarakat membunyikan polopalo, maka tandanya ada hewan buas yang merusak, memakan tanaman atau ada kejadian lainnya.

Peran dan nilai guna Polopalo mengalami perubahan dari media komunikasi menjadi media hiburan pada abad ke 19, karena keinginan raja dan masyarakat akan kebutuhan seni hiburan dimana polopalo yang semula berada dalam lingkaran masyarakat masuk dalam lingkaran kerajaan. Peran masuknya polopalo dalam arena kerajaan bukan hanya semata karena hiburan, melainkan juga karena faktor politik, dimana kesenian juga digunakan sebagai alat kedekatan pemimpin dengan masyarakatnya.

Era milenial, pengembangan Polopalo mengalami kemunduran bahkan cenderung tergerus oleh kekeliruan intepretasi, tetapi kekeliruan intepretasi akibat dari nilai guna yang kurang tepat justru menempatkan polopalo sebagai "pahlawan" dalam aspek ekonomi, budaya dan sosial seperti penggunaan polopalo dalam Lihuta Lo Polopalo, sebuah kompetisi memainkan polopalo dimana bunyi polopalo yang mencapai sasaran dinyatakan sebagai juara atau pemenang kompetisi.

Lihuta lo Polopalo merupakan sebuah tindakan sosial rasionalis instrumentalis, karena adanya timbal balik dari aktor terhadap lingkungan sekitar. Posisi polopalo dalam lihuta lo polopalo memang menimbulkan beberapa perdebatan, terdapat pihak yang pro dan kontra. Bagi masyarakat yang pro atau setuju dengan lihuta lo polopalo maka kompetisi ini dinilai sebagai langkah dan upaya menyelamatkan, melestarikan polopalo terutama jenis pentatonis (motoliyongo, moelenggengo, mobulongo dan 
modulodu'o) yang sekarang ini mulai tergerus oleh kehadiran polopalo jenis diatonis (7 nada). Tetapi selain itu juga mendekatkan jarak silaturahmi antara masyarakat karena yang hadir atau meningkuti tidak hanya masyarakat setempat, melainkan warga dari berbagai kota/kab di Gorontalo.

Masyarakat yang kontra, mempersepsikan bahwa kompetisi ini sebagai sarana sosial-politis untuk penyamaran taruhan karena terdapat nilai nominal yang diperebutkan.

Perkembangan peran Polopalo dalam masyarakat Gorontalo terus mengalami pasang surut, walaupun muncul pro dan kontra ketika lihuta lo polopalo dilaksanakan, tetapi dampak yang diakibatkan dalam sebuah seni pertunjukkan berupa kompetisi polopalo ini cukup besar, yaitu pembangunan infrastruktur; seperti jalan dan jembatan yang menuju lokasi kompetisi yang dulunya belum bagus, dengan adanya kompetisi ini menjadi lebih baik selain itu taraf perekonomian warga sekitar juga menjadi lebih meningkat, karena warga mendapatkan tambahan pendapatan dari konsumsi-produksi makanan, minuman, bahan bakar dan parkir kendaraan.

Bukan hanya warga yang memperoleh peningkatan ekonomi tetapi ahli Polopalo mendapatkan hasil ekonomi yang baik dari penjualan polopalo dan menjadi juri lomba. Adanya nilai nominal dalam lihuta lo Polopalo merupakan sebuah dilema dualitas, dimana adanya nilai taruhan secara tidak langsung mendegradasi nilai Polopalo tetapi sisi lain menyatakan bahwa dari nominal pendaftaran yaitu $25 \%$ dari pendaftaran (Rp. 16.000,-) berarti Rp. 4.000,- dapat digunakan untuk memberi kehidupan bagi masyarakat baik dari sisi infrastruktur, sosial, ekonomi dan budaya.

Obyektifitas Polopalo dalam aktifitas masyarakat merupakan relasi antara intra musikal dengan ekstra musikal, dimana terjadi metaphor nilai guna polopalo dalam lihuta lo polopalo dari fungsi latens menjadi fungsi manifest, karena dampak yang diakibatkan oleh sebuah kompetisi terhadap sendi-sendi kehidupan masyarakat.

\section{Simpulan}

Etno organologi akustik sebagai sebuah pendekatan terhadap polopalo bukan hanya dalam ruang lingkup bentuk dan akustik, melainkan pendekatan ini digunakan untuk mengetahui Polopalo dari pemilihan material bahan, organologi akustik, falsafah yang melandasi sampai dampak dari nilai guna yang diakibatkan dalam berbagai bidang kehidupan pada tataran aspek keilmuan.

Konteks perkembangan sains, maka Polopalo diuraikan dalam model 
eksperimen pengukuran yang hasilnya dikaitkan dengan pemetaan terukur yang mengubah konsep audio menjadi visual yang memapu ditelaah sebagai musik sebagai dirinya sendiri yang berkaitan dengan musik sebagai konsep atau proses kognitif, sedangkan konteks budaya adalah polopalo diposisikan pada musik sebagai perilaku yang dikaitkan dengan filosofi masyarakat.

\section{E. Daftar Pustaka}

Alperson, Philips. 1994. What a Music? An Introduction to the Philosophy of music. University Park, PA: Pennsylvania State University Press

Cresswell, John. 2012. Research Design: Pendekatan kualitatif, Kuantitatif, dan Mixed edisi ketiga, terj. Achmad Fawaid. Yogyakarta: Pustaka Pelajar

Hui Hung. 2011. One Music? Two Musics? How Many Musics? Etnomusicology vocal and Instrumen With FMRI, Desertation. Ohio State University.

Kadis, Jay. 2015. Acoustic: a study of sound waves. For Educational Only. Modul pembelajaran akustik, tidak terbit

Ohi, Rahmawti. 2014. Peran Polopalo dalam Aktivitas Masyarakat Kabupaten Bone Bolango Gorontalo, Thesis Program Pengkajian dan Penciptaan Musik Institut Seni Indonesia Yogyakarta. ISI Yogyakarta.

Ohi, Rahmawati 2019. Nilai Organologi akustik Polopalo, Jurnal Selonding
Vol 15, No. 1 2019, Jurusan Etnomusikologi ISI Yogyakarta.

Vincent Doutaut and Marthee Cutite. An aid to innovation in instrumentmaking: a collaborative approach between workshops and research laboratories Acoustics in Practice International e-Journal of the European Acoustics Association (EAA) Vol. 2 • No. 1 • January 2014

Tresh, John and Emily Dolan. 2013. Toward A new Organology: Instrumen of musics and science. Osiris 2013. Page 278-298 